Research Paper: Immunology

\title{
Tumor necrosis factor-a-induced protein 8-like 2 (TIPE2) is associated with immune phases of patients with chronic hepatitis B
}

\author{
Yu-Chen Fan ${ }^{1,2}$, Yuan-Yuan Zhang ${ }^{3}$, Na Wang ${ }^{1}$, Yan-Yan Sun ${ }^{1}$ and Kai Wang ${ }^{1,2}$ \\ ${ }^{1}$ Department of Hepatology, Qilu Hospital of Shandong University, Jinan, China \\ 2 Institute of Hepatology, Shandong University, Jinan, China \\ ${ }^{3}$ Department of Neurology, Jinan Central Hospital Affiliated to Shandong University, Jinan, China \\ Correspondence to: Kai Wang, email: wangdoc876@126.com
}

Keywords: TIPE2; immune phase; chronic hepatitis B; immune clearance; interleukin; Immunology and Microbiology Section; Immune response; Immunity

Received: August 24, 2016

Accepted: February 15, 2017

Published: February 24, 2017

Copyright: Fan et al. This is an open-access article distributed under the terms of the Creative Commons Attribution License (CC-BY), which permits unrestricted use, distribution, and reproduction in any medium, provided the original author and source are credited.

\section{ABSTRACT}

Tumor necrosis factor-a-induced protein 8-like 2 (TIPE2) is a newly negative immune regulator but its role in different immune phases of patients with chronic hepatitis B (CHB) is unknown. We determined the mRNA levels of TIPE2, interleukin-6, interleukin-10, tumor necrosis factors-a and interferon-y in peripheral blood mononuclear cells from 205 naïve treated CHB patients and 15 healthy controls by quantitative real time polymerase chain reaction. Intrahepatic TIPE 2 protein was also determined using immunohistochemistry staining. The TIPE2 mRNA level in CHB patients was significantly higher than that in healthy controls. Moreover, the TIPE2 mRNA level in immune clearance (IC) phases was significantly higher than that in immune tolerance (IT) phase; whereas TIPE2 MRNA in HBeAg negative hepatitis (ENH) was obviously higher than low replication (LR) phase. Furthermore, the optional cut off values of 2.02 and 1.59 for TIPE2 mRNA level have strong power in identifying IC and ENH from IT and LR. In addition, intrahepatic TIPE2 protein was predominantly located in hepatocyte plasma and correlated with hepatic inflammatory and fibrosis. Multivariate analysis showed tumor necrosis factors- $a$, interferon- $y$ and HBV DNA load were independently correlated with TIPE2 level. In conclusion, TIPE2 might be associated to the immune clearance of patients with chronic hepatitis $B$.

\section{INTRODUCTION}

Hepatitis B virus (HBV) is a serious public problem and about more than 350 million subjects are HBV carriers globally [1]. Immune response is recognized as one of the main determinants for the progression of chronic HBV infection [2]. Due to the characteristics of immune statue, the natural course of patients with chronic hepatitis $\mathrm{B}$ (CHB) can be typically divided into four phases: immune tolerance (IT), immune clearance (IC), low or no-replicative (LR), and hepatitis B e antigen ( $\mathrm{HBeAg}$ )negative hepatitis (ENH) [1, 3-6]. Understanding the natural course of CHB makes a lot of sense on exploring the progression of this disease, searching for potential therapeutic target, and optimizing antiviral treatment $[7,8]$. However, the exact function and mechanism of immune regulation in chronic hepatitis B remains still obscure.

Tumor necrosis factor- $\alpha$-induced protein 8 -like 2(TIPE2) is a novel molecular belonging to TNFAIP8 family, and orchestrates immune homeostasis by binding to $\mathrm{T}$ cell receptors and toll-like receptors [9]. TIPE2 can promote Fas-mediated apoptosis and stimulate the activation of cell death $[9,10]$. Previous studies demonstrated that TIPE2 knockout cells exert strong biological function stimulated by activating toll-like receptor and $\mathrm{T}$ cell receptor signals pathway [11]. Furthermore, the levels of cytokines including interleukin(IL)-1, IL-6, IL-12, and tumor necrosis factor (TNF)- $\alpha$ as well as the inhibitory cytokine IL-10 were significantly produced in TIPE2-deficient mice [9]. TIPE2 has also been reported to regulate innate immunity to 
bacteria and dsRNA viruses by targeting the Rac GTPase, and down-regulation of TIPE2 is associated with increased phagocytosis and bacterial killing [12, 13]. Accelerating evidences support the hypothesis that TIPE2 might contribute to the pathogenesis in a variety of chronic inflammatory diseases, autoimmune disorders, stroke, diabetic nephropathy, tumors and atherosclerosis [14-24]. Recent studies demonstrated that TIPE2 production was inhibited in HBV specific T cell response and significantly correlated with the grades of hepatic inflammation in the patients with viral hepatitis $[11,14]$. T cell immunity exerts dual roles in the clearance of HBV replication and contributes to the progression of chronic HBV infection [25]. Therefore, TIPE2 might participate in the immune phases of patients with chronic hepatitis B.

Currently, we have previously revealed that TIPE2 contributed to the occurrence of liver failure and peripheral TIPE2 mRNA level might be a biomarker for predicting the 3-month mortality of liver failure [26, 27]. However, the potential role of TIPE2 in the various immune phases of chronic hepatitis B remains still unknown. This present study was to assess the expression of TIPE2 in the natural history of chronic hepatitis B with different immune phases. Here, we first determined the mRNA expression levels of TIPE2, IL-6, IL-10, TNF- $\alpha$, and IFN- $\gamma$ in peripheral blood mononuclear cells from 205 naïve treated patients with chronic hepatitis B, as well as 15 healthy controls. Second, we also determined the location and expression of intrahepatic TIPE2 protein in liver tissue. Furthermore, we investigated the possible diagnosis value of TIPE2 mRNA in discriminating different immune stages of CHB patients if necessary.

\section{RESULTS}

\section{General characteristics}

Figure 1 was shown for describing the inclusion of patients in our present study. From Dec 2013 to Jan 2015, a total of 245 patients with HBsAg positive for more than 6 months were hospitalized and retrospective collected. Of whom, a total of 40 patients were excluded as the following reasons: 5 for non-B hepatitis virus infection, 4 for severe alcohol abuse, 5 for hepatocellular carcinoma, 4 for co-infection with other liver diseases, 2 for hematologic disorders, and 20 for the history of anti-HBV treatment within the near one year. Finally, a total of 205 naïve CHB patients were included and were

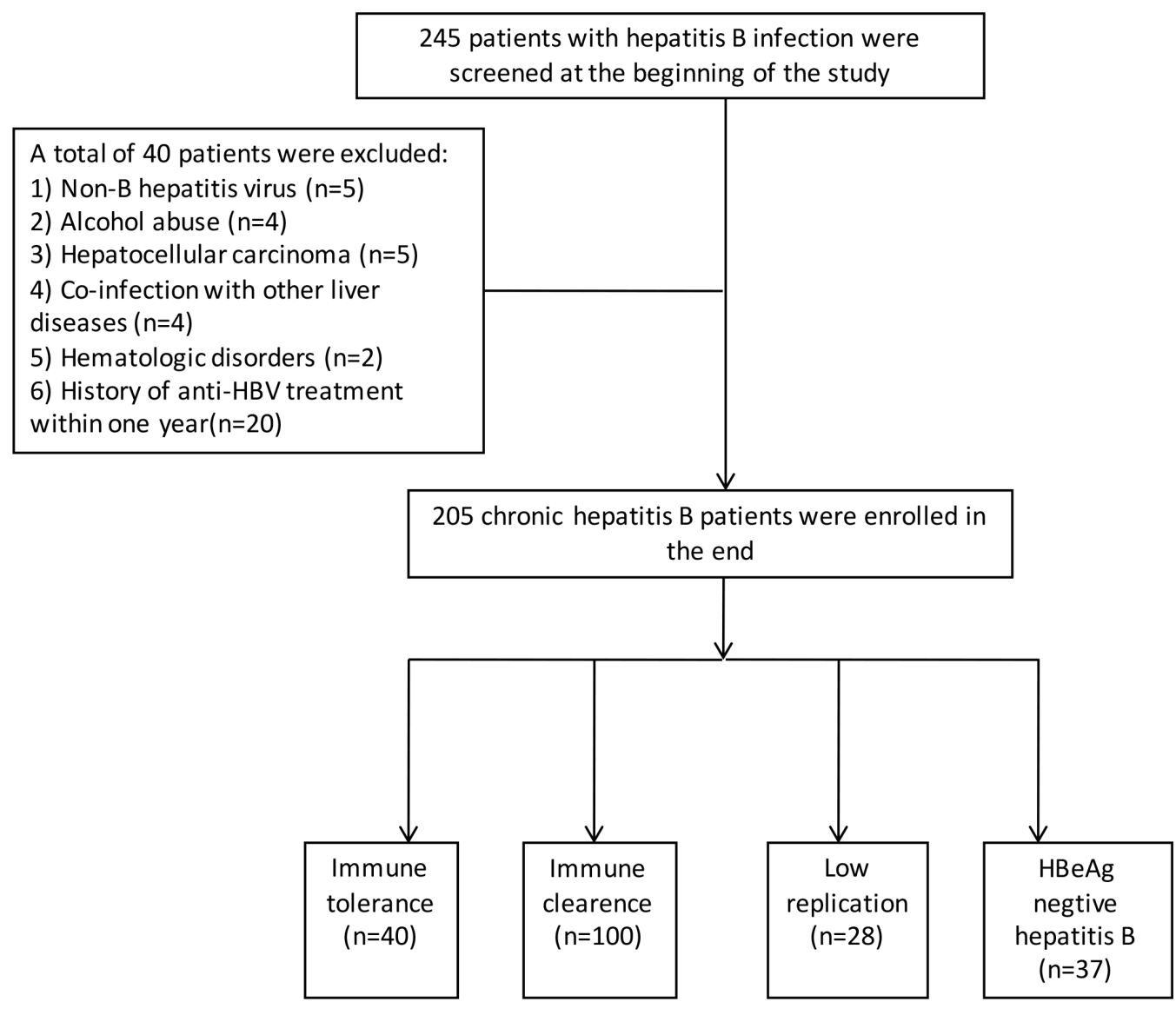

Figure 1: Flowchart for the inclusive procession of all the subjects in this present study. 
Table 1: Baseline characteristics of the enrolled patients.

\begin{tabular}{|l|l|l|l|}
\hline Variables & CHB group $(\boldsymbol{n}=\mathbf{2 0 5})$ & HC group $(\boldsymbol{n}=\mathbf{1 5})$ & $\boldsymbol{P}$ Values \\
\hline Male (n, \%) & $152(74.1)$ & $11(73.3)$ & $0.945 \mathrm{a}$ \\
\hline Age (years) & $40(28-47)$ & $38(26-45)$ & $>0.05 \mathrm{~b}$ \\
\hline HBeAg+(n, \%) & $140(68.3)$ & NA & \\
\hline HBVDNA+(n, \%) & $164(80.0)$ & NA & \\
\hline Log10 (HBVDNA load) & $5.74(3.92-7.22)$ & NA & \\
\hline HBsAg(IU/mL) & $3769(994.5-5711)$ & NA & \\
\hline ALT (U/L) & $120(39-265.5)$ & $16(12.0-25.0)$ & $<0.001^{\mathrm{b}}$ \\
\hline AST (U/L) & $57(32.5-132)$ & $12(7.0-20.5)$ & $<0.001^{\mathrm{b}}$ \\
\hline TBIL (umol/L) & $17.7(11.7-41.7)$ & $10.5(6.7-12.3)$ & $<0.001^{\mathrm{b}}$ \\
\hline ALB (g/L) & $42(37.7-45.1)$ & $50(42-61)$ & $<0.001^{\mathrm{b}}$ \\
\hline PT-INR & $1.00(0.95-1.06)$ & $0.80(0.72-1.01)$ & $0.688^{\mathrm{b}}$ \\
\hline PTA (\%) & $92(77.5-102)$ & $89(78-93)$ & $0.237^{\mathrm{b}}$ \\
\hline AFP (ng/ml) & $29.6(13.2-41.2)$ & $25(19-31)$ & $<0.001 \mathrm{~b}$ \\
\hline Cr (umol/L) & $62(52-69.6)$ & $63(52-69)$ & $0.282 \mathrm{~b}$ \\
\hline WBC (E+09/L) & $5.40(4.60-6.69)$ & $7.65(6.32-8.65)$ & $<0.001 \mathrm{~b}$ \\
\hline HGB (g/L) & $125(110-145.5)$ & $143(130-156)$ & $<0.001^{\mathrm{b}}$ \\
\hline PLT (E+09/L) & $187(154-225.5)$ & $201(157-234)$ & $0.006^{\mathrm{b}}$ \\
\hline
\end{tabular}

Quantitative variables were expressed as the median (centile 25; centile 75).

Categorical variables were expressed as number $(\%)$.

Table 2: Baseline characteristics of immune phases of chronic hepatitis $B$.

\begin{tabular}{|c|c|c|c|c|c|}
\hline \multirow{2}{*}{ Variable } & \multicolumn{2}{|l|}{ HBeAg (+) } & \multicolumn{2}{|l|}{ HBeAg(-) } & \multirow[t]{2}{*}{$P$} \\
\hline & IT $(n=40)$ & IC $(n=100)$ & $\operatorname{LR}(n=28)$ & ENH $(n=37)$ & \\
\hline Male $(\%)$ & $25(62.5)$ & $78(78.0)$ & $19(67.8)$ & $28(75.7)$ & $0.554^{\mathrm{a}}$ \\
\hline Age (years) & $32(24-39)$ & $38(28-46)$ & $41(26-51)$ & $40(32-54)$ & $<0.001^{\text {b }}$ \\
\hline $\mathrm{HBeAg}+(\%)$ & $40(100)$ & $100(100)$ & $0(0)$ & $0(0)$ & $<0.001^{\mathrm{a}}$ \\
\hline HBVDNA+(\%) & $40(100)$ & $100(100)$ & $7(25.0)$ & $35(94.6)$ & $<0.001^{\mathrm{a}}$ \\
\hline Log10 (HBVDNA load) & $7.70(7.25-8.18)$ & $5.07(4.75-6.73)$ & $0(0-3.19)$ & $5.30(4.04-6.04)$ & $<0.001^{\mathrm{b}}$ \\
\hline HBsAg(IU/mL) & $4489(3595-6512)$ & 2332(838-5407) & $1956(212-3775)$ & $2905(1770-4161)$ & $<0.001^{\mathrm{b}}$ \\
\hline ALT (U/L) & $29(21-39)$ & $263(1367-453)$ & $35(24-41)$ & $253(123-465)$ & $<0.001^{\mathrm{b}}$ \\
\hline $\operatorname{AST}(\mathrm{U} / \mathrm{L})$ & $27(22-33)$ & $117(67-232)$ & $20(18-36)$ & $152(98-319)$ & $<0.001^{\mathrm{b}}$ \\
\hline TBIL (umol/L) & $13.1(7.4-18.6)$ & $49.8(18.4-87.1)$ & $12.5(9.5-17.7)$ & $18(15-25)$ & $<0.001^{b}$ \\
\hline $\operatorname{ALB}(\mathrm{g} / \mathrm{L})$ & $43.6(42.3-48.3)$ & $41.8(39.1-44.7)$ & $43.2(40.1-46.2)$ & $44.8(40.8-47.9)$ & $<0.001^{\mathrm{b}}$ \\
\hline
\end{tabular}

Quantitative variables were expressed as the median (centile 25; centile 75). Categorical variables were expressed as number $(\%)$.

a, Chi-square test; b, Kruskal-Wallis test.

IT, immune tolerance phase; IC, immune clearance phase; LR, low-replicative phase; ENH, HBeAg-negative hepatitis phase; HBeAg, hepatitis B e antigen; HBsAg, hepatitis B surface antigen;ALT, alanine aminotransferase; AST, aspartate aminotransferase; TBIL, total bilirubin; ALB, albumin.

When the serum viral load of HBV DNA is less than $500 \mathrm{IU} / \mathrm{mL}$, it is recognized as negative. 
divided into four groups: 40 patients for IT phase, 100 for IC phase, 28 for LR phase, and 37 for ENH phase. The general characteristics of CHB patients and healthy controls were shown in Table 1.

\section{The mRNA levels of TIPE2 and its associated cytokines in peripheral blood mononuclear cells from CHB patients and healthy controls}

In this present study, we first compared the differences of TIPE2 and its associated cytokines between $\mathrm{CHB}$ patients and healthy controls. Figure 2A illustrated that the relative expression of TIPE2 mRNA in CHB patients was significantly higher than that in healthy controls (CHB: 2.061 [1.285, 3.08] vs. 0.49 [0.28, 0.86], $P<0.01$ ), indicating TIPE2 might participate in the progression of HBV infection. Then we have determined the relative mRNA levels of TIPE2 associated cytokines including IL-6, IL-10, TNF- $\alpha$, and IFN- $\gamma$ in CHB patients and healthy controls. As shown in Figure 2B, we demonstrated that the mRNA expression levels of IL6 , TNF- $\alpha$ and IL-10 in CHB patients were significantly increased compared with healthy controls (IL-6, 23.12 [4.4, 23.57] vs. 0.93 [0.72, 1.05], $P<0.01$; TNF- $\alpha, 5.68$ $[4.62,6.90]$ vs. $1.04[0.63,3.17], P<0.01$; IL-10, 3.24 $[2.95,3.54]$ vs. $0.49[0.28,0.86], P<0.01)$, whereas we did not find any significant differences of IFN- $\gamma$ between the two groups $(1.61[1.21,1.92]$ vs. 1.90 [0.92, 2.66], $P>$ $0.05)$.

\section{Expression of TIPE2 mRNA from peripheral blood mononuclear cells and TIPE2 associated cytokines in the different immune phases of CHB patients}

The general characteristics of CHB patients stratified by the different immune phases were shown in Table 2. The median and interquartile ranges for the relative mRNA expression of TIPE2 were 1.3 [0.997, 1.847] for IT patients, $2.396[1.712,3.53]$ for IC patients, 1.45 [0.976, 2.197] for LR patients, and 2.45 [1.95, 3.24] for $\mathrm{ENH}$ patients. In Figure 2C, we demonstrated that the relative expression of TIPE2 mRNA in each of the four immune phases was significantly higher than healthy controls $(0.49[0.28,0.86])$. Furthermore, we found that relative expression of TIPE2 mRNA in IC/ENH phases shared similar higher trend for TIPE2 mRNA level compared with those with LR/IT phases (all $P<0.05$, respectively). Furthermore, we did not find any significant difference of TIPE2 mRNA in ENH and IC phases $(P>0.05)$, as well as LR and IT phases $(P>0.05)$. Current evidences suggested that immune response contribute to progression from IT to IC, and LR to ENH, and then leading to virus elimination. Therefore, we investigated the differences of
TIPE2 associated cytokines in the four immune phases. Figure 2D revealed that the level of IL-10 in IC group $(3.33[3.12,4.65])$ was significantly higher than that in LR group (3.03 [2.79, 3.39], $P<0.05)$ or IT group (3.11 $[0.31,3.27], P<0.05)$, whereas we also demonstrated the significant difference of IL-10 between IT group and ENH group (3.11 [0.31, 3.27] vs. 3.37 [3.08, 3.71], $P<0.05)$. However, we did not find any significant differences of IL6 , TNF- $\alpha$ and IFN- $\gamma$ between any two of the four phases.

To explore the possible relationship of TIPE2 with HBV replication, we also compared the TIPE2 mRNA levels in the CHB patients stratified by the statue of HBeAg and HBVDNA as shown in Figure 2E. No significant difference was found between $\mathrm{CHB}$ patients with $\mathrm{HBeAg}$ positive (IT+IC) and those without $\mathrm{HBeAg}$ positive (LR+ENH) (2.091 [1.395, 2.711] vs.2.045 [1.28, $3.145], P>0.05)$. Of note, we demonstrated a significant higher level of TIPE2 mRNA in HBVDNA positive patients compared with HBVDNA negative patients (2.131 [1.382, 3.285] vs. 1.56 [0.870, 2.391], $P<0.05)$. Furthermore, the receiver operating characteristic (ROC) analysis was performed to identify whether TIPE2 mRNA could discriminate IC phase from IT phase, and ENH phase from LR phase. Figure $2 \mathrm{~F}$ showed the area under the receiver operating characteristic (AUROC) curves of TIPE2 mRNA for predicting the incidence of IC in the IT individuals was 0.765 (95\% confidence interval $0.686-0.832, P<0.001$ ), and the optimal cutoff value was 2.02 with a sensitivity of $66.00 \%$ and a specificity of $87.5 \%$. Meanwhile, the AUROC of TIPE2 mRNA for the incidence of ENH in the LR individuals was 0.751 (95\% confidence interval $0.628-0.850, P<0.001$ ), and the optimal cutoff value was 1.59 with a sensitivity of $89.19 \%$ and a specificity of $67.86 \%$.

\section{Intrahepatic TIPE2 expression was associated with inflammation and fibrosis in CHB patients}

We also determined the expression of intrahepatic TIPE2 protein from $25 \mathrm{CHB}$ patients and 4 normal livers from liver transplant donors (Table 3). Representative immunohistochemical images of TIPE2 in CHB patients were shown in Figure 3A-3D. The local TIPE2 protein was highly stained and mainly visualized in hepatocyte cytoplasm. Digital image analysis showed that there were significant differences of relative mean integrated optical density for hepatic TIPE2 in CHB patients and normal livers $(P<0.05)$ in Figure 3E. Furthermore, we also found that the relative mean integrated optical densities for hepatic TIPE2 protein in inflammation G3/4 and fibrosis S3/4 were significantly higher compared to that of the inflammation $\mathrm{G} 1 / 2$ and fibrosis $\mathrm{S} 1 / 2(P<0.05$, Figure $3 \mathrm{~F})$. Importantly, we also demonstrated that the relative mean density of TIPE2 expression was significantly increased in $\mathrm{CHB}$ patients with $\mathrm{G} 1 / 2$ than those with $\mathrm{G} 0(P<0.05)$. 
A

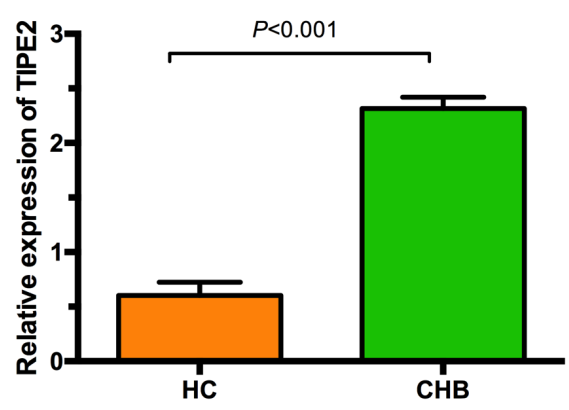

C

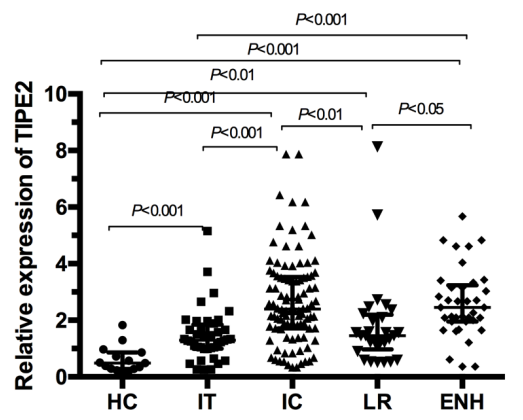

E

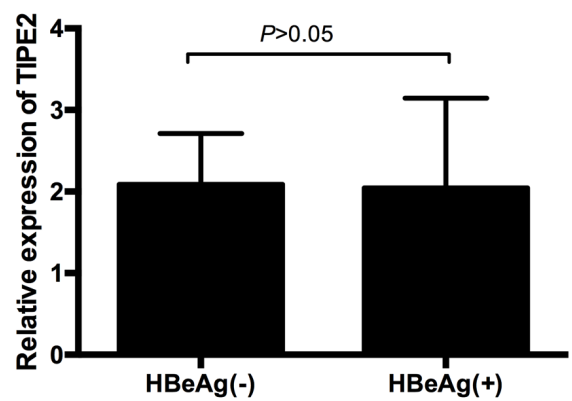

$\mathbf{F}$

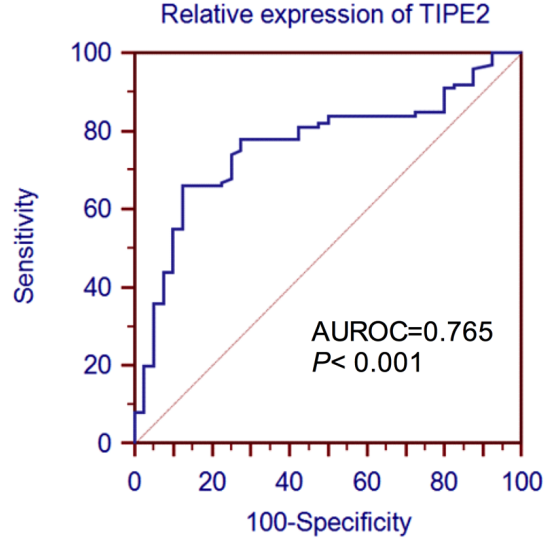

B

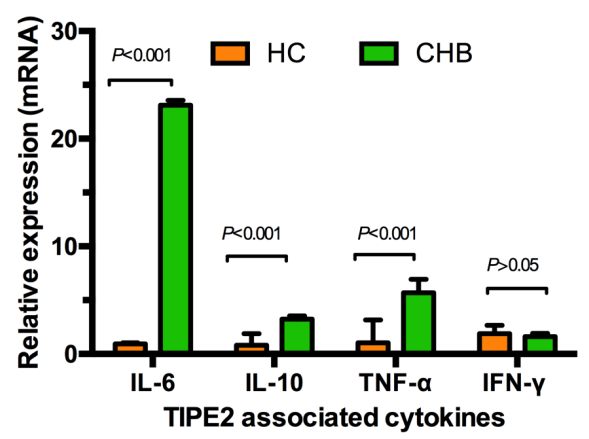

D
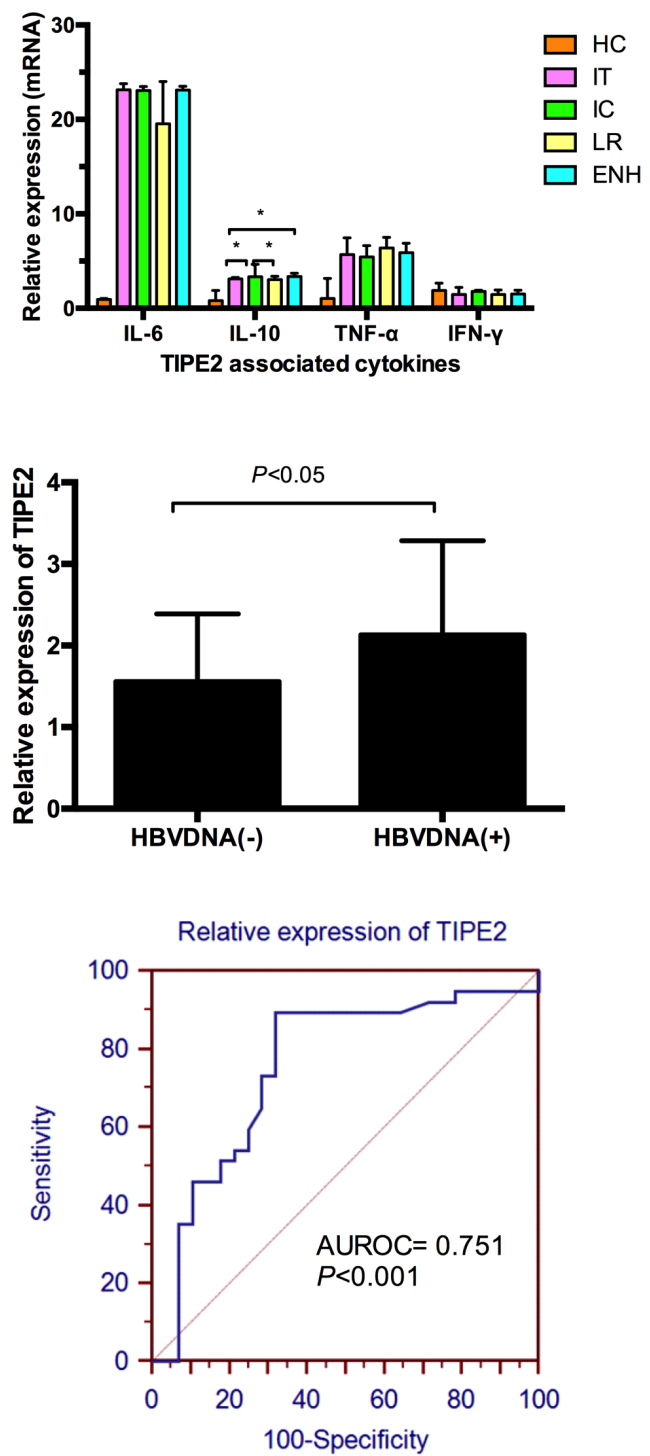

Figure 2: Relative expression of TIPE2 mRNA and TIPE2 associated cytokines in peripheral blood mononuclear cells in different immune phases of chronic hepatitis and healthy controls. A. The relative expression of TIPE2 mRNA in peripheral blood mononuclear cells in all the patients and healthy controls. B. The mRNA expression levels of IL-6, IL-10, TNF- $\alpha$, and IFN- $\gamma$ in all the patients and healthy controls. C. Expression of TIPE2 mRNA from peripheral blood mononuclear cells in healthy controls and CHB patients with IT, IC, LR, and ENH. D. The mRNA expression levels of IL-6, IL-10, TNF- $\alpha$, and IFN- $\gamma$ in healthy controls and CHB patients with IT, IC, LR and ENH. E. Expression of TIPE2 mRNA in CHB patients stratified by the statue of HBeAg and HBVDNA. F. ROC analysis of the predicative accuracy for TIPE2 mRNA in discriminating IC from IT and ENH from LR. 
A

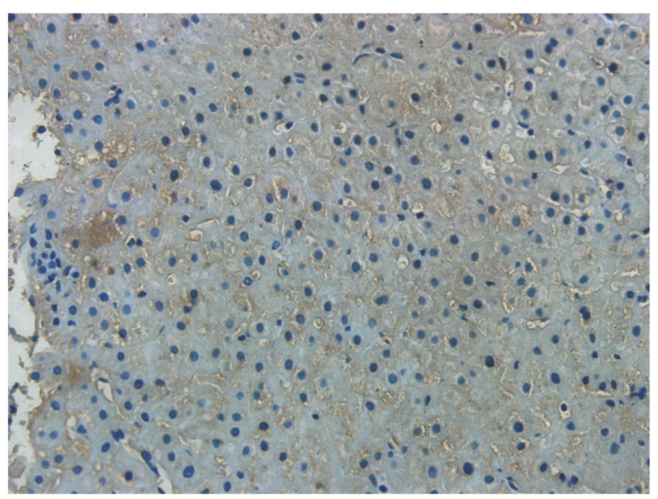

G0SO

C

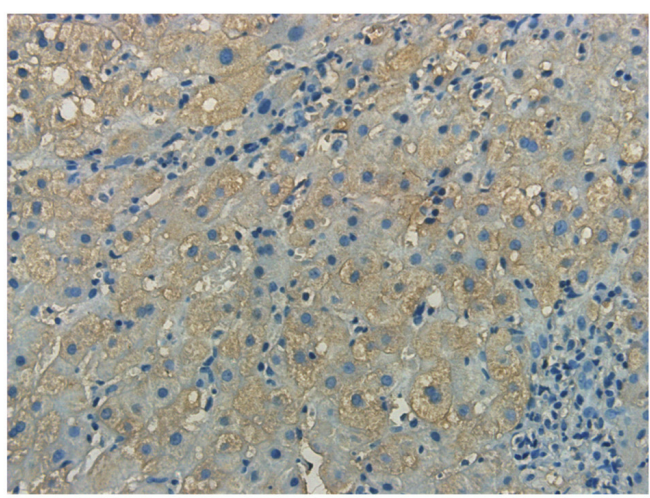

G2S3
B

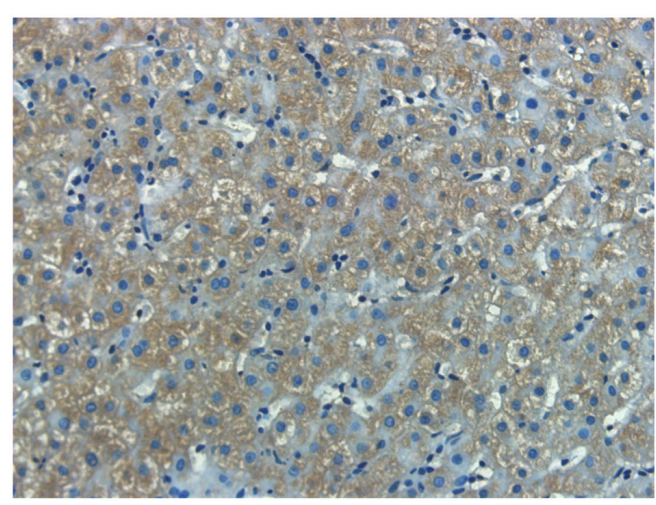

G1S1

D

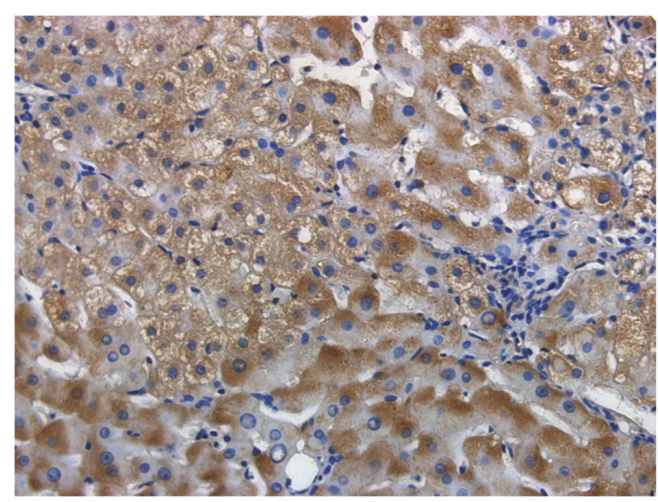

G3S4

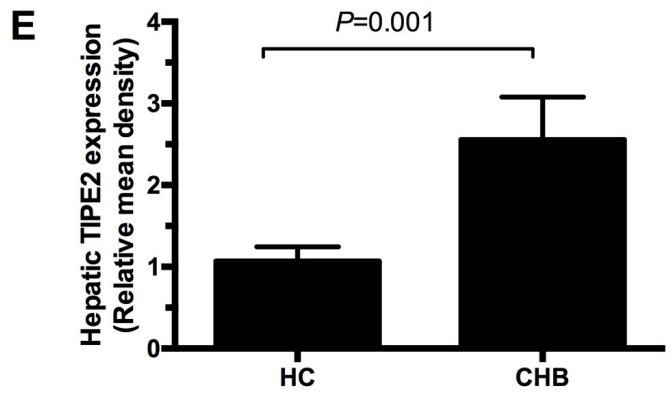

F

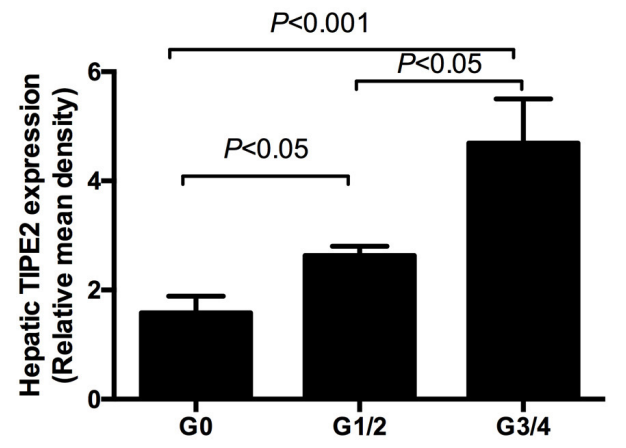

G

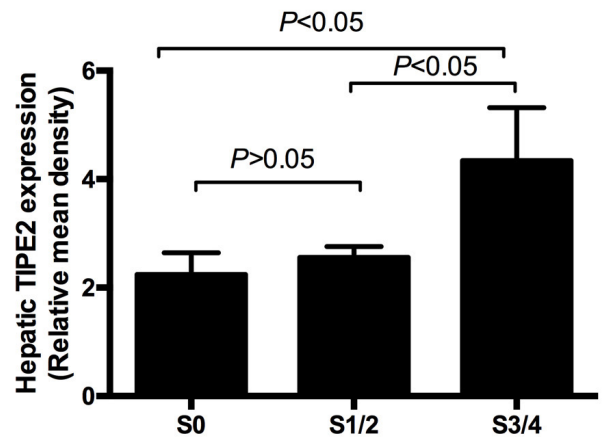

Figure 3: Expression of TIPE2 protein in liver tissue of CHB patients. A.-D. The positive staining for TIPE2 was found mainly in the hepatocytes $(200 \times)$. E. Relative mean density analysis showed the difference in hepatic TIPE2 staining between CHB group and healthy controls. F. Expression of hepatic TIPE2 staining between inflammation grade 0, grade (1-2) and grade (3-4). G. Expression of hepatic TIPE2 staining between fibrosis stage (3-4), stage (1-2), and fibrosis stage 0 . 
Table 3: Baseline characteristics of the CHB patients receiving a liver biopsy.

\begin{tabular}{|l|l|l|l|c|c|c|c|c|c|}
\hline Cases & Gender & Age & $\begin{array}{l}\text { G } \\
\text { (Inflammation) }\end{array}$ & $\begin{array}{l}\text { S } \\
\text { (Fibrosis) }\end{array}$ & $\begin{array}{l}\text { ALT } \\
(\mathbf{U} / \mathbf{L})\end{array}$ & $\begin{array}{l}\text { AST } \\
(\mathbf{U} / \mathbf{L})\end{array}$ & $\begin{array}{l}\text { HBeAg } \\
(+/-)\end{array}$ & $\begin{array}{l}\text { HBVDNA } \\
(+/-)\end{array}$ & $\begin{array}{l}\text { Immune } \\
\text { phase }\end{array}$ \\
\hline 1 & Female & 29 & 0 & 0 & 16 & 26 & - & + & IT \\
\hline 2 & Female & 24 & 0 & 0 & 123 & 72 & + & + & IC \\
\hline 3 & Male & 40 & 0 & 1 & 49 & 47 & + & + & IC \\
\hline 4 & Male & 38 & 0 & 1 & 116 & 41 & + & + & IC \\
\hline 5 & Female & 56 & 0 & 1 & 23 & 24 & - & - & LR \\
\hline 6 & Female & 27 & 1 & 0 & 10 & 17 & - & + & LR \\
\hline 7 & Male & 29 & 1 & 0 & 67 & 45 & + & + & IC \\
\hline 8 & Male & 46 & 1 & 0 & 54 & 47 & - & + & ENH \\
\hline 9 & Male & 38 & 1 & 1 & 109 & 87 & + & + & IC \\
\hline 10 & Female & 35 & 1 & 1 & 97 & 48 & - & + & ENH \\
\hline 11 & Female & 31 & 1 & 0 & 11 & 21 & + & + & IT \\
\hline 12 & Male & 29 & 1 & 1 & 56 & 35 & + & + & IC \\
\hline 13 & Male & 40 & 0 & 2 & 21 & 25 & + & + & IT \\
\hline 14 & Male & 47 & 1 & 2 & 102 & 77 & + & - & ENH \\
\hline 15 & Female & 19 & 2 & 0 & 23 & 42 & + & + & IT \\
\hline 16 & Male & 40 & 2 & 1 & 18 & 18 & + & - & LR \\
\hline 17 & Male & 31 & 2 & 2 & 155 & 74 & + & + & IC \\
\hline 18 & Male & 36 & 2 & 1 & 262 & 94 & + & + & IC \\
\hline 19 & Male & 23 & 3 & 2 & 225 & 110 & + & + & IC \\
\hline 20 & Female & 41 & 3 & 3 & 89 & 62 & + & + & IC \\
\hline 21 & Male & 20 & 2 & 3 & 107 & 61 & - & - & ENH \\
\hline 22 & Female & 47 & 3 & 4 & 310 & 105 & + & + & IC \\
\hline 23 & Male & 31 & 4 & 3 & 166 & 121 & + & + & IC \\
\hline 24 & Female & 47 & 2 & 4 & 132 & 105 & + & + & IC \\
\hline 25 & Male & 39 & 4 & 3 & 176 & 102 & + & + & IC \\
\hline Control1 & Male & 39 & 0 & 0 & 22 & 35 & - & - & NA \\
\hline Control2 & Male & 34 & 0 & 0 & 31 & 28 & - & - & NA \\
\hline Control3 & Male & 41 & 0 & 0 & 18 & 29 & - & - & NA \\
\hline Control4 & Female & 28 & 0 & 0 & 27 & 21 & - & - & NA \\
\hline
\end{tabular}

IT, immune tolerance phase; IC, immune clearance phase; LR, low-replicative phase; ENH, HBeAg-negative hepatitis phase; $\mathrm{HBeAg}$, hepatitis B e antigen; ALT, alanine aminotransferase; AST, aspartate aminotransferase;

There was no significant difference of the relative mean integrated optical density for hepatic TIPE2 protein between fibrosis $\mathrm{S} 0$ and $\mathrm{S} 1 / 2(P>0.05)$.

\section{Correlations between TIPE2 mRNA levels and clinical characteristics in CHB patients}

We performed univariate and multivariate analysis to investigate the possible associations of TIPE2 mRNA with clinical characteristics in CHB patients. In table 4, the relative expression of TIPE2 mRNA was significantly positively correlated with HBV DNA load $(\mathrm{r}=0.200, P$ $<0.001)$, alanine aminotransferase (ALT) $(\mathrm{r}=0.300, \mathrm{P}<$ $0.001)$, aspartate aminotransferase (AST) $(\mathrm{r}=0.283, P<$ $0.001)$, and IL-10 $(\mathrm{r}=0.147, P<0.05)$; whereas TIPE2 mRNA was negatively correlated with PT-INR $(\mathrm{r}=-0.151$, $P<0.001)$, IL-6(r $=-0.163, P<0.05)$, TNF- $\alpha(\mathrm{r}=-0.159$,
$P<0.05)$, and IFN- $\gamma(\mathrm{r}=-0.183, P<0.01)$. Multivariate analysis showed that three independent variables were associated with TIPE2 mRNA: HBV DNA load $(\beta=$ $0.196, P<0.05)$, TNF- $\alpha(\beta=-0.142, P<0.05)$, and IFN- $\gamma$ $(\beta=-0.151, P<0.05)$.

\section{DISCUSSION}

TIPE2 is a novel identified negative regulator in immune homeostasis but its role in the natural history of chronic HBV infection has not been well investigated. In this present study, we determined the dynamic expression of TIPE2 mRNA in PBMCs in different immune phases of chronic HBV infection. To our knowledge, this is the first report to investigate the relationship between TIPE2 and immune phases in the natural history of chronic HBV infection. 
Table 4: Correlations between TIPE2 mRNA levels and other parameters using univariate and multivariate analysis in all the patients and healthy controls.

\begin{tabular}{|l|c|c|c|c|}
\hline \multirow{2}{*}{ TIPE2 mRNA vs. } & \multicolumn{2}{|c|}{ Univariate analysis } & \multicolumn{2}{c|}{ Multivariate analysis } \\
\cline { 2 - 5 } & $\mathbf{R}$ & $\boldsymbol{P}$ & $\boldsymbol{\beta}$ & $\boldsymbol{P}$ \\
\hline Gender & 0.120 & 0.087 & & \\
\hline Age $(\mathrm{years})$ & -0.094 & 0.180 & & \\
\hline HBeAg(IU/mL) & 0.018 & 0.795 & & \\
\hline HBVDNA & 0.200 & 0.004 & 0.196 & 0.007 \\
\hline HBsAg(IU/mL) & 0.081 & 0.250 & & \\
\hline ALT (U/L) & 0.300 & 0.000 & -0.027 & 0.857 \\
\hline AST (U/L) & 0.283 & 0.000 & 0.063 & 0.673 \\
\hline TBIL $(\mathrm{umol} / \mathrm{L})$ & 0.106 & 0.129 & & \\
\hline ALB $(\mathrm{g} / \mathrm{L})$ & 0.032 & 0.646 & & \\
\hline PT-INR & -0.151 & 0.031 & 0.026 & 0.714 \\
\hline WBC $(\mathrm{E}+09 / \mathrm{L})$ & 0.044 & 0.535 & & \\
\hline HGB $(\mathrm{g} / \mathrm{L})$ & -0.005 & 0.942 & & \\
\hline PLT $(\mathrm{E}+09 / \mathrm{L})$ & -0.002 & 0.977 & & \\
\hline IL-6 $(\mathrm{pg} / \mathrm{ml})$ & -0.163 & 0.020 & -0.035 & 0.624 \\
\hline IL-10 $(\mathrm{pg} / \mathrm{ml})$ & 0.147 & 0.036 & 0.098 & 0.177 \\
\hline TNF- $\alpha(\mathrm{pg} / \mathrm{ml})$ & -0.159 & 0.023 & -0.142 & 0.044 \\
\hline IFN- $\gamma(\mathrm{pg} / \mathrm{ml})$ & -0.183 & 0.009 & -0.151 & 0.032 \\
\hline
\end{tabular}

Firstly, we demonstrated that the relative level of TIPE2 mRNA in CHB patients was significantly higher than healthy controls. These results are in disagreement with the previous report [14]. The discrepancy of the data might be due to the different case number with different immune stages involved in each study. Accumulating evidences indicated that TIPE2 might limit $\mathrm{T}$ cell responses during chronic viral infections [28]. In our study, TIPE2 might suppress HBV-mediated innate and adaptive immune response and contribute to the persistence of HBV infection. Furthermore, we reported that the level of TIPE2 mRNA in IC phase was significantly higher than IT phase; whereas the level of TIPE2 mRNA in ENH phase was also obviously higher than LR phase. These results suggested that immune-activated CHB patients (IC and ENH phases) had significantly higher TIPE2 levels than immune tolerant and/or inactive patients, and strongly supported the hypothesis that TIPE2 might participate in the activation of immune response in chronic HBV infection.

In this present study, we reported the elevated levels of IL-6, IL-10 and TNF- $\alpha$ in CHB patients compared with healthy controls. Several studies previously reported that TIPE2 could binds to caspase- 8 and inhibit activating protein-1 and nuclear factor-kappaB(NF- $\mathrm{kB}$ ) activation [9]. Meanwhile, it has been reported that the activated NF$\mathrm{\kappa B}$ can stimulate the expression of inflammatory cytokine [29], including TNF- $\alpha$, IL-6, IL-1 and interferon- $\beta$ [30].
In agreement with these reports, we demonstrated that the increased TIPE2 level was negatively correlated with IL6 , TNF- $\alpha$ and IFN- $\gamma$ in CHB patients, and was positively correlated with IL-10. In addition, IL-10 has also been reported to be correlated with chronic progression of HBV infection and predict the prognosis of liver failure $[31,32]$. Therefore, these results strongly suggested that TIPE2 might play an essential role in the T helper cellular immunity in the pathogenesis of HBV infection. Furthermore, we also revealed that the level of IL-10 in IC phase was significantly higher than that in LR or ENH phase, indicating that TIPE2 and IL-10 might exert important roles in the progression of IC from IT. However, the mechanism for TIPE2 in the regulation of immune clearance remains future research.

To testify the possible association of TIPE2 mRNA with HBV replication, we also investigated the TIPE2 mRNA levels stratified by HBeAg statue and HBV DNA. There were no significant differences in the levels of TIPE2 mRNA between HBeAg positive and negative patients and it was hypothesized that $\mathrm{HBeAg}$ might not be a crucial factor for regulating TIPE2 expression. However, we found a weak significant difference of TIPE2 in HBVDNA positive and negative group. Of note, we also demonstrated that HBV DNA was an independent positive factor for TIPE2 mRNA using multivariate analysis. These results might be explained by the phenomena that HBV DNA usually showed higher level in IC stage 
Table 5: Primers sequence used for real-time RT-PCR.

\begin{tabular}{|l|l|}
\hline Gene & Primer sequence $\left(5^{\prime}-3^{\prime}\right)$ \\
\hline TIPE2 & Forward GGAACATCCAAGGCAAGACTG \\
\hline & Reverse AGCACCTCACTGCTTGTCTCATC \\
\hline TNF- $\alpha$ & Forward AAGCCTGTAGCCCATGTTGT \\
\hline & Reverse CAGATAGATGGGCTCATACC \\
\hline IL-6 & Forward ACCCCTGACCCAACCACAAAT \\
\hline & Reverse AGCTGCGCAGAATGAGATGAGTT \\
\hline IL-10 & Forward ATGCTTCGAGATCTCCGAGA \\
\hline & Reverse AAATCGATGACAGCGCCGTA \\
\hline IFN- $\gamma$ & Forward GCAGAGCCAAATTGTCTCCT \\
\hline & Reverse ATGCTCTTCGACCTCGAAAC \\
\hline$\beta$-actin & Forward ATGGGTCAGAAGGATTCCTATGTG \\
\hline & Reverse CTTCATGAGGTAGTCAGTCAGGTC \\
\hline
\end{tabular}

than ENH stage. In this present study, we provided the hypothesis that TIPE2 mRNA might be as a biomarker to discriminate IC phase from IT phase, and ENH phase from LR phase. We reported that a cut off values of 2.02 and 1.59 for the level of TIPE2 mRNA have significant power in discriminating IC from IT, and ENH for LR respectively. These results might provide a new diagnosis tool for early detecting IC phase from IT phase, and ENH phase from LR phase. However, a larger, multi-centered and prospective cohort should be established for validate this hypothesis.

Consistent with the notion that TIPE2 is a negative regulator for immune homeostasis, TIPE2 is a cytoplasmic protein preferentially in lymphoid tissues, especially highly in monocytes and $\mathrm{T}$ cells [33-35]. However, human TIPE2 was also expressed in a wide variety of non-hematopoietic cell types, including hepatocytes [35]. In this present study, we demonstrated that TIPE2 protein was mainly distributed in hepatocytes plasma in CHB patients. The expression of human TIPE2 in hepatocyte suggested that TIPE2 may be involved in maintaining immune privilege liking immune negative regulators [35]. We also reported that intrahepatic TIPE2 protein in inflammation $\mathrm{G} 3 / 4$ and fibrosis $\mathrm{S} 3 / 4$ was significantly increased compared to that of inflammation G3/4 and fibrosis $S 1 / 2$. It could be explained by the fact that inflammation mainly involves in local hepatocytes and TIPE2 might participate in this progression.

There are also some limitations in the present study. First, we determined the TIPE2 mRNA and protein levels in relative small number of patients. In this study, we only included 29 liver tissue due to the fact that only a small number of patients accept liver biopsy in real world. Second, other HBV associated liver diseases including cirrhosis, acute hepatitis, and liver failure should be included to explore the comprehensive role of TIPE2 in the whole progression of HBV infection. In fact, there should be a series studies on this issue, we have recently reported the expression of TIPE2 in acute-on-chronic hepatitis B liver failure [27]. Third, our study is a crosssectional cohort but not a perspective study; therefore, we did not include resolved HBV cases and patients with/ after treatment. Finally, silence of TIPE2 gene in cell lines and HBV transgenic mice should be comprehensively investigated for the interplay of TIPE2 and HBV in the future.

In summary, TIPE2 might be associated with immune clearance of patients with chronic hepatitis B. Furthermore, the optional cut off values of 2.02 and 1.59 for TIPE2 mRNA as biomarker have strong power in identifying CHB patients with IC and ENH phases from patients with IT and LR phases.

\section{PATIENTS AND METHODS}

\section{Patients}

A total of 205 naïve treated CHB patients with CHB were enrolled in the Department of Hepatology, Qilu Hospital of Shandong University from Dec 2013 to Jan 2015. Of these patients, there were 25 CHB patients receiving liver biopsy. 15 healthy volunteers were included as health controls. Additionally, four liver specimens from healthy liver transplant donors serve as normal tissue. $\mathrm{CHB}$ were defined as the positivity of HBsAg for more than 6 months and no history of anti-HBV treatment within one year. IT phase was identified as $\mathrm{HBeAg}$ positive with a high virus load $>5 \mathrm{E}+07 \mathrm{IU} / \mathrm{mL}$ and persistently normal $\operatorname{ALT}(\mathrm{n}=40)$. IC phase was identified as $\mathrm{HBeAg}$ positive with an elevated ALT and a virus load $>2000 \mathrm{IU} / \mathrm{mL}$ ( $\mathrm{n}=$ 100). LR phase was identified as HBeAg-negative with virus load $<2000 \mathrm{IU} / \mathrm{mL}$ and persistently normal ALT(n $=28)$. ENH phase was identified as HBeAg negative with virus load $>2000 \mathrm{IU} / \mathrm{mL}$ and elevated ALT level $(\mathrm{n}=37)$. 
The upper limit of normal of ALT was $40 \mathrm{U} / \mathrm{L}$. Liver samples were histologically graded and staged according to the Scheuer scoring [36].

In addition, exclusive criteria are as the following: (1) infected with human immunodeficiency virus, hepatitis $\mathrm{C}$ virus, hepatitis $\mathrm{D}$ virus and autoimmune or metabolic liver disease;(2) had a treatment-free interval within one year; (3) hematologic disorders;(4) severe alcohol abuse. All the subjects have written informed consents which were approved by the local Ethic Committee at Qilu Hospital of Shandong University according to the Declaration of Helsinki [37].

\section{RNA and cDNA preparation from PBMC}

$5 \mathrm{ml}$ of Natrium citrate-anticoagulated peripheral blood from $\mathrm{CHB}$ patients and heathy controls were collected. After Ficoll-Paque Plus (GE Healthcare, Uppsala, Sweden) density gradient centrifugation, peripheral blood mononuclear cells from the interface were collected and washed three times with phosphatebuffered saline. RNA was then extracted using TRIzol (Invitrogen, Carlsbad, CA, USA). 2 uL of RNA were reversely transcribed into cDNA using first-strand cDNA synthesis kit (Fermentas, Vilnius, Lithuania). Finally, the cDNA quantification was determined by reversetranscriptase polymerase chain reaction (RT-PCR) method.

\section{Quantitative real-time PCR}

The expression of TIPE2 in gene was examined by real-time PCR. $\beta$-actin was used as the endogenous control. Real-time PCR was conducted with Lightcycler 480 (Roche Diagnostics, Germany). Real-time PCR was preformed using a SYBR Premix Ex Taq $^{\mathrm{TM}}$ (Takara, Japan) according to the manufacture's instructions in a total volume of $20 \mu \mathrm{l}$ containing $1 \mu \mathrm{lcDNA}, 0.4 \mu \mathrm{l}$ specific primers, $10 \mu \mathrm{l}$ SYBR Green premix, and $8.2 \mu \mathrm{lddH} 2 \mathrm{O}$. The primers sequences were list in Table 5. The reaction of PCR procedure was the following: denaturation at $95{ }^{\circ} \mathrm{C}$ for $30 \mathrm{~s}, 40$ cycles at $95{ }^{\circ} \mathrm{C}$ for $5 \mathrm{~s}, 60{ }^{\circ} \mathrm{C}$ for $30 \mathrm{~s}$ and $72{ }^{\circ} \mathrm{C}$ for $30 \mathrm{~s}$. Each sample was carried out in triplicate. LightCycler 480 Software (Roche Diagnostics, Germany) was used for data analysis, and the results were performed using the comparative $\left(2^{-\Delta \Delta \mathrm{Ct}}\right)$ method.

\section{Immunohistochemistry staining}

The intrahepatic expression of TIPE2 was determined using Polink-2 plus ${ }^{\circledR}$ Polymer HRP Detection System (Zhongshan Golden bridge Biotechnology, China). Briefly, the paraffin sections $(5 \mu \mathrm{m})$ were deparaffinized using xylene and hydrated through graded ethanol (100\%, $96 \%, 90 \%$, and $70 \%$ ) and distilled water. Endogenous peroxidase was blocked in $3 \% \mathrm{H}_{2} \mathrm{O}_{2}$ for 15 minutes. After PBS washing, the slides were incubated using rabbit antiTIPE2 polyclonal antibody (dilution 1:50, ProteinTech Group (Chicago, IL, USA) at $4^{\circ} \mathrm{C}$ for overnight and then polymer Helper or poly-HRP anti-rabbit IgG for $20 \mathrm{~min}$ at $37^{\circ} \mathrm{C}$. After counterstaining with hematoxylin, the slides were dehydrated and mounted for viewing. Negative control was performed by same method of immunohistochemical staining except for replacing antiTIPE2 polyclonal antibody with PBS. The immunostaining intensity were captured by a camera (OLYMPUS IX83, Tokyo, Japan) attached to the microscope. The Mean integrated optical density (integrated optical density sum/ positive area sum) of all the diaminobenzidine-stained areas of each photo was measured by Image-Pro Plus 6.0 software (Media Cybernetics, Bethesda, MD).

\section{Clinical parameters}

Blood samples were taken from each participant. The serum biochemical parameters (COBAS integra 800, Roche Diagnostics, Germany) included AST, ALT, total bilirubin (TBIL), albumin (ALB), and creatinine (Cr). Hemostasis parameters (ACL TOP 700, Instrument laboratory, USA) included PT-INR and PTA. WBC, HGB and PLT were also determined (Sysmex XE-2100, Sysmex Corporation, and Japan). Hepatitis B virus markers, including $\mathrm{HBsAg}, \mathrm{HBeAg}$, and anti-HBe were measured (cobas 6000 analyzer series, Roche Diagnostics, Switzerland).

\section{Statistical analysis}

Data were shown as median values and interquartile ranges. Comparison between groups was performed by the Kruskal-Wallis analysis. Multivariate regression model and Spearman's tests were performed for correlation analyses. AUROC was used to determine the diagnostic accuracy. $P<0.05$ was considered as statistical significance. All the statistical analyses were preformed using the IBM SPSS 19.0 software (SPSS Inc., Chicago, IL, USA).

\section{ACKNOWLEDGMENTS}

This work is supported by the grants from National Natural Science Foundation of China (81201287, 81371832 ), Key Project of Chinese Ministry of Science and Technology (2012ZX10002007, 2013ZX10002001), Science and Technology Development Project of Shandong Province (2012GSF11851), Qingdao people's Livelihood Science and technology project(15-9-291-NSH), and the Fundamental Research Funds of Shandong University-Clinical Research Project of Qilu Hospital(2014QLKY11). 


\section{CONFLICTS OF INTEREST}

The authors declare that they have no conflicts of interest.

\section{REFERENCES}

1. Vanwolleghem $\mathrm{T}$, Hou J, van Oord G, Andeweg AC, Osterhaus AD, Pas SD, Janssen HL, Boonstra A. Reevaluation of hepatitis B virus clinical phases by systems biology identifies unappreciated roles for the innate immune response and B cells. Hepatology. 2015; 62:87-100.

2. Boni C, Laccabue D, Lampertico P, Giuberti T, Vigano M, Schivazappa S, Alfieri A, Pesci M, Gaeta GB, Brancaccio G, Colombo M, Missale G, Ferrari C. Restored Function of HBV-Specific T Cells After Long-term Effective Therapy With Nucleos(t)ide Analogues. Gastroenterology. 2012; 143:963-973.

3. Yim HJ, Lok ASF. Natural history of chronic hepatitis B virus infection: What we knew in 1981 and what we know in 2005. Hepatology. 2006; 43:S173-S181.

4. Papatheodoridis G, Buti M, Cornberg M, Janssen H, Mutimer D, Pol S, Raimondo G, Liver EAS. EASL Clinical Practice Guidelines: Management of chronic hepatitis B virus infection. Journal of Hepatology. 2012; 57:167-185.

5. Fattovich G, Bortolotti F, Donato F. Natural history of chronic hepatitis B: Special emphasis on disease progression and prognostic factors. Journal of Hepatology. 2008; 48:335-352.

6. Song LW, Liu PG, Liu CJ, Zhang TY, Cheng XD, Wu HL, Yang HC, Hao XK, Yuan Q, Zhang J, Kao JH, Chen DS, Chen PJ, et al. Quantitative hepatitis B core antibody levels in the natural history of hepatitis B virus infection. Clinical Microbiology and Infection. 2015; 21:197-203.

7. Rehermann B and Bertoletti A. Immunological aspects of antiviral therapy of chronic hepatitis B virus and hepatitis $\mathrm{C}$ virus infections. Hepatology. 2015; 61:712-721.

8. Fan YC, Zhang YY, Sun YY, Wang N, Xiao XY, Wang $\mathrm{K}$. Altered expression of A20 gene in peripheral blood mononuclear cells is associated with the progression of chronic hepatitis B virus infection. Oncotarget. 2016; 7:68821-68832. doi: 10.18632/oncotarget.11993.

9. Sun H, Gong S, Carmody RJ, Hilliard A, Li L, Sun J, Kong L, Xu L, Hilliard B, Hu S, Shen H, Yang X, Chen YH. TIPE2, a negative regulator of innate and adaptive immunity that maintains immune homeostasis. Cell. 2008; 133:415-426.

10. Ruan Q, Wang P, Wang T, Qi J, Wei M, Wang S, Fan T, Johnson D, Wan X, Shi W, Sun H, Chen YH. MicroRNA-21 regulates $\mathrm{T}$-cell apoptosis by directly targeting the tumor suppressor gene Tipe2. Cell death \& disease. 2014; 5:e1095.

11. Zhang W, Zhang J, Zhao L, Shao J, Cui J, Guo C, Zhu F, Chen YH, Liu S. TIPE2 protein negatively regulates HBV-specific CD8(+) T lymphocyte functions in humans.
Molecular immunology. 2015; 64:204-209.

12. Wang Z, Fayngerts S, Wang P, Sun H, Johnson DS, Ruan Q, Guo W, Chen YH. TIPE2 protein serves as a negative regulator of phagocytosis and oxidative burst during infection. Proceedings of the National Academy of Sciences of the United States of America. 2012; 109:15413-15418.

13. Sun HH, Zhuang GH, Chai LH, Wang ZJ, Johnson D, Ma YF, Chen YHH. TIPE2 Controls Innate Immunity to RNA by Targeting the Phosphatidylinositol 3-Kinase-Rac Pathway. Journal of immunology. 2012; 189:2768-2773.

14. Xi WJ, Hu YJ, Liu YG, Zhang J, Wang L, Lou YW, Qu ZH, Cui J, Zhang GZ, Liang XH, Ma CH, Gao CJ, Chen YH, et al. Roles of TIPE2 in hepatitis B virus-induced hepatic inflammation in humans and mice. Molecular Immunology. 2011; 48:1203-1208.

15. Kong L, Liu K, Zhang YZ, Jin M, Wu BR, Wang WZ, Li W, Nan YM, Chen YH. Downregulation of TIPE2 mRNA expression in peripheral blood mononuclear cells from patients with chronic hepatitis C. Hepatology International. 2013; 7:844-849.

16. Li D, Song LJ, Fan YC, Li X, Li YJ, Chen J, Zhu FL, Guo C, Shi YY, Zhang LN. Down-regulation of TIPE2 mRNA expression in peripheral blood mononuclear cells from patients with systemic lupus erythematosus. Clin Immunol. 2009; 133:422-427.

17. Lou YW, Sun HH, Morrissey S, Porturas T, Liu SX, Hua XX, Chen YHH. Critical Roles of TIPE2 Protein in Murine Experimental Colitis. Journal of immunology. 2014; 193:1064-1070.

18. Zhang Y, Wei XB, Liu LX, Liu SX, Wang ZY, Zhang B, Fan BX, Yang F, Huang SY, Jiang F, Chen YHH, Yi F. TIPE2, a Novel Regulator of Immunity, Protects against Experimental Stroke. Journal of Biological Chemistry. 2012; 287:32546-32555.

19. Zhang SY, Zhang Y, Wei XB, Zhen JH, Wang ZY, Li MY, Miao W, Ding H, Du PC, Zhang WC, He M, Yi F. Expression and regulation of a novel identified TNFAIP8 family is associated with diabetic nephropathy. Bba-Mol Basis Dis. 2010; 1802:1078-1086.

20. Cao XL, Zhang L, Shi YY, Sun Y, Dai S, Guo C, Zhu FL, Wang Q, Wang JN, Wang XY, Chen YHH, Zhang LN. Human tumor necrosis factor (TNF)-alpha-induced protein 8-like 2 suppresses hepatocellular carcinoma metastasis through inhibiting Rac1. Mol Cancer. 2013; 12:149.

21. Zhao Q, Zhao M, Dong T, Zhou C, Peng Y, Zhou X, Fan B, Ma W, Han M, Liu S. Tumor Necrosis Factor-alphaInduced Protein-8 Like-2 (TIPE2) Upregulates p27 to Decrease Gastic Cancer Cell Proliferation. Journal of Cellular Biochemistry. 2015; 116:1121-1129.

22. Zhang G, Zhao L, Wang Y, Shao J, Cui J, Lou Y, Geng M, Zhang N, Chen YH, Liu S. TIPE2 protein prevents injuryinduced restenosis in mice. Biochimica et biophysica acta. 2015; 1852:1574-1584.

23. Lou Y, Liu S, Zhang C, Zhang G, Li J, Ni M, An G, 
Dong M, Liu X, Zhu F, Zhang W, Gao F, Chen YH, et al. Enhanced Atherosclerosis in TIPE2-Deficient Mice Is Associated with Increased Macrophage Responses to Oxidized Low-Density Lipoprotein. Journal of immunology. 2013; 191:4849-4857.

24. Li Z, Guo C, Liu X, Zhou C, Zhu F, Wang X, Wang Q, Shi Y, Wang J, Zhao W, Zhang L. TIPE2 suppresses angiogenesis and non-small cell lung cancer (NSCLC) invasiveness via inhibiting Racl activation and VEGF expression. Oncotarget. 2016; 7:62224-62239. doi: 10.18632/oncotarget.11406.

25. Rehermann B, Nascimbeni M. Immunology of hepatitis $\mathrm{B}$ virus and hepatitis $\mathrm{C}$ virus infection. Nature reviews Immunology. 2005; 5:215-229.

26. Wang LY, Fan YC, Zhao J, Gao S, Sun FK, Han J, Yang $\mathrm{Y}$, Wang K. Elevated expression of tumour necrosis factor-alpha-induced protein 8 (TNFAIP8)-like 2 mRNA in peripheral blood mononuclear cells is associated with disease progression of acute-on-chronic hepatitis B liver failure. Journal of viral hepatitis. 2014; 21:64-73.

27. Fan YC, Wang N, Sun YY, Xiao XY, Wang K. TIPE2 mRNA Level in PBMCs Serves as a Novel Biomarker for Predicting Short-Term Mortality of Acute-on-Chronic Hepatitis B Liver Failure: A Prospective Single-Center Study. Medicine. 2015; 94:e1638.

28. Wang LIN, Zhao C, Peng Q, Shi J, Gu G. Expression levels of CD28, CTLA-4, PD-1 and Tim-3 as novel indicators of T-cell immune function in patients with chronic hepatitis B virus infection. Biomedical Reports. 2014; 2:270-274.

29. Jang E-J, Nahm D-H, Jang Y-J. Mouse monoclonal autoantibodies penetrate mouse macrophage cells and stimulate NF- $\kappa \mathrm{B}$ activation and $\mathrm{TNF}-\alpha$ release. Immunology Letters. 2009; 124:70-76.

30. Takeda K, Akira S. Microbial recognition by toll-like receptors. Journal of Dermatological Science. 2004; 34:7382.

31. Wang N, Fan YC, Xia HH, Sun YY, Wang K. Plasma interleukin-10 predicts short-term mortality of acute-onchronic hepatitis B liver failure. Aliment Pharmacol Ther. 2016; 43:1208-1221.

32. Wilson EB, Brooks DG. The role of IL-10 in regulating immunity to persistent viral infections. Current topics in microbiology and immunology. 2011; 350:39-65.

33. Zhang L, Shi Y, Wang Y, Zhu F, Wang Q, Ma C, Chen YH, Zhang L. The unique expression profile of human TIPE2 suggests new functions beyond its role in immune regulation. Molecular Immunology. 2011; 48:1209-1215.

34. Freundt EC, Bidere N,Lenardo MJ. A different TIPE of immune homeostasis. Cell. 2008; 133:401-402.

35. Zhang G, Hao C, Lou Y, Xi W, Wang X, Wang Y, Qu Z, Guo C, Chen Y, Zhang Y, Liu S. Tissue-specific expression of TIPE2 provides insights into its function. Molecular Immunology. 2010; 47:2435-2442.

36. Wang H, Yan R, Zhou Y, Wang MS, Ruo GQ, Cheng MJ. A scoring system for predicting significant fibrosis in chronic hepatitis B patients with normal or mildly elevated alanine aminotransferase levels. J Clin Gastroenterol. 2015; 49:69-75.

37. Hellmann F, Verdi M, Schlemper BR Jr, Caponi S. 50th anniversary of the Declaration of Helsinki: the double standard was introduced. Archives of medical research. 2014; 45:600-601. 